\title{
Mapping the initial DNA breaks in apoptotic Jurkat cells using ligation-mediated PCR
}

\author{
QY Liü ${ }^{\star 1}$, M Ribecco-Lutkiewicz', C Carson ${ }^{1}$, L Testolin ${ }^{1}$, \\ D Bergeron, T Kohwi-Shigematsu ${ }^{2}$, PR Walker ${ }^{1}$ and M Sikorska ${ }^{1}$ \\ ${ }^{1}$ Apoptosis Research Group, Institute for Biological Sciences, National \\ Research Council of Canada, Ottawa, Ontario, Canada K1A OR6 \\ 2 Department of Cell and Molecular Biology, Lawrence Berkeley National \\ Laboratory, Berkeley, CA 94720, USA \\ * Correspondence: M Sikorska and QY Liu, Apoptosis Research Group, Institute \\ for Biological Sciences, National Research Council of Canada, 1200 Montreal \\ Road, Bldg M-54, Ottawa, Ontario, Canada K1A 0R6. Tel: +16139935916 or \\ +1613990 0850; Fax: +1 613990 7963; \\ E-mail: marianna.sikorska@nrc.ca
}

Received 8.7.02; revised 4.9.02; accepted 16.9.02

Edited by $S$ Nagata

\begin{abstract}
Apoptotic DNA degradation could be initiated by the accumulation of single-strand (ss) breaks in vulnerable chromatin regions, such as base unpairing regions (BURs), which might be preferentially targeted for degradation by both proteases and nucleases. We tested this hypothesis in antiFas-treated apoptotic Jurkat cells. Several nuclear proteins known for their association with both MARs and the nuclear matrix, that is, PARP, NuMA, lamin B and SATB1, were degraded, but the morphological rearrangement of the BURbinding SATB1 protein was one of the earliest detected changes. Subsequently, we have identified several genes containing sequences homologous to the 25 bp BUR element of the $\operatorname{lgH}$ gene, a known SATB1-binding site, and examined the integrity of genomic DNA in their vicinity. Multiple ss breaks were found in close proximity to these sites relative to adjacent regions of DNA. Consistent with our prediction, the results indicated that the initiation of DNA cleavage in antiFas-treated Jurkat cells occurred within the BUR sites, which likely became accessible to endonucleases due to the degradation of BUR-binding proteins.

Cell Death and Differentiation (2003) 10, 278-289. doi:10.1038/ sj.cdd. 4401146
\end{abstract}

Keywords: MARs; BUR-binding proteins; proteolysis; endonucleolysis

Abbreviations: ss, single strand; ds, double strand; BURs, base unpairing regions; MARs, matrix attachment regions; HMG, highmobility group phosphoprotein gene; MYC, c-myc protooncogene; PRM, protamine gene cluster; PDH, pyruvate dehydrogenase alpha subunit gene; $R C L$, red cell type low molecular weight acid phosphatase gene; CAD, caspase-activated DNase; ICAD, inhibitor of caspase-activated DNase; DFF, DNA fragmentation factor; EMSA, electrophoretic mobility shift assay; SW,
Southwestern blotting; LM-PCR, Ligation-mediated PCR; PFGE, pulsed field gel electrophoresis; CAGE, conventional agarose gel electrophoresis

\section{Introduction}

DNA cleavage and the associated collapse of chromatin structure have long been considered to be the fundamental biochemical and morphological hallmarks of apoptosis. Despite the well-established history of these critical events, the molecular mechanisms that initiate the nuclear breakdown processes have not been fully elucidated. Apoptotic DNA cleavage produces a characteristic pattern of both high and low molecular weight fragments. Initially, large $50-300 \mathrm{kbp}$ DNA fragments are generated and, as degradation progresses, oligonucleosomal ladders are produced, at least in some cell types. ${ }^{1,2}$ The large DNA fragments are thought to arise from the cleavage of DNA domains at matrix attachment regions (MARs) and may result from the accumulation of single-strand (ss) breaks introduced in the vulnerable DNA regions in contact with the nuclear matrix..$^{3-7}$ Many chromatinassociated proteins, such as DNA topoisomerase II, PARP, NuMA, lamin B, SAF-A and SATB1, have been shown to undergo site-specific proteolysis during apoptosis. ${ }^{8-13}$ This process can be temporally linked to the initiation of DNA cleavage, suggesting that the latter may be a consequence of the loss of a protective protein coating.

The organization of chromatin within the eukaryotic nucleus involves the attachment of DNA loops to the nuclear matrix at AT-rich sequences located at the base of the loop. These sequences are known as scaffold or matrix attachment regions, S/MAR. ${ }^{14-16}$ Although MARs can be found throughout the genome, they are often located at the boundaries of transcription units near enhancer regions or within origins of DNA replication. Typically, MARs of several kilobases are found at the borders of chromatin domains, whereas shorter elements occur within certain enhancers or in introns. ${ }^{15}$ Based on information assembled in a database on scaffold/ matrix attached regions, ${ }^{17}$ the mean length of a MAR sequence is approximately $2 \mathrm{~kb}$. MARs contain short elements, approximately 150-200 bp, called base unpairing regions or BURs, which under negative superhelical strain, potentiate the unwinding of DNA strands. ${ }^{18,19}$ Although no primary consensus sequence for BURs has been identified, it has been documented that they contain a core unwinding element of approximately $25 \mathrm{bp}$. The unwinding element consists of ATC tracts, which confer both the base unpairing properties and high-affinity binding to the nuclear matrix. ${ }^{20-22}$ It is well documented that these elements represent proteinbinding sites and several BUR-binding proteins have been identified, including SATB1, SAF-A, PARP, Ku subunit of DNA-PK, Bright and HMG-I(Y). ${ }^{13,21,23,24}$ Proteolysis of these proteins during apoptosis has been well documented, ${ }^{25,26}$ but the relationship between their cleavage and the initiation of 
DNA degradation has not been explored. We predicted that degradation of BUR-binding proteins renders DNA at these specific sites vulnerable to initial cleavage events during apoptosis. We have used a well-characterized model of apoptosis, the anti-Fas treatment of Jurkat cells, to explore this link.

From a Blast search of the Genbank database, we selected a number of genes, namely high-mobility group phosphoprotein (HMG), c-myc proto-oncogene (MYC), protamine gene cluster (protamine 1, protamine 2 and transition protein, $\mathrm{PRM})$, pyruvate dehydrogenase alpha subunit gene $(\mathrm{PDH})$ and low molecular weight acid phosphatase (red cell type, $\mathrm{RCL}$ ), which contain sequences highly similar to the $25 \mathrm{bp}$ BUR element of the IgH gene and known SATB1-binding site. ${ }^{21,27}$ Subsequently, we have shown by electrophoretic mobility shift assay (EMSA) and Southwestern (SW) blotting (SW) that these sequences interacted with a subset of nuclear proteins and that this binding was compromised in cells undergoing apoptosis. Furthermore, using ligation-mediated PCR (LM-PCR) we obtained evidence for the accumulation of ss DNA breaks in close proximity to these sites, relative to adjacent stretches of DNA. To our knowledge, this is the first evidence that identifies BUR elements as the sites where the initiation of DNA cleavage in apoptosis might occur

\section{Results}

\section{Temporal correlation between nuclear proteolysis and endonucleolysis}

Jurkat cells undergo apoptosis readily in response to anti-Fas treatment. However, cell death is an asynchronous process and, at present, there is no clear understanding of whether the cell-cycle-related changes in chromatin influence the molecular mechanisms of DNA degradation. In order to avoid this complication, we have blocked DNA synthesis in Jurkat cells by an overnight aphidicolin treatment prior to the induction of apoptosis. This treatment blocked approximately $80 \%$ of the cells in G1 without any negative effect on their viability, as measured by MTT assay (data not shown). These synchronized cells were subsequently treated with anti-Fas antibody. A loss of cell viability became noticeable after $3 \mathrm{~h}$, and more pronounced after $4 \mathrm{~h}$ of treatment. At this time point, approximately $35 \%$ of the cells were dead (Table 1 ). However, apoptotic DNA fragments of $50 \mathrm{~kb}$ and smaller were already clearly seen in samples isolated after $2 \mathrm{~h}$ of antiFas treatment (Figure 1a). These DNA fragments were subjected to further analysis by two-dimensional DNA electrophoresis with a denaturation step in alkaline buffer preceding conventional electrophoresis in the second dimension. This procedure reveals the presence of ss breaks in cleaved DNA fragments. ${ }^{7,28}$ Indeed, the denaturation treatment resulted in the liberation of a smear of ss fragments of all sizes, not only from the apoptotic DNA fragments but also from the high molecular weight DNA, which remained in the

Table 1 Loss of cell viability in response to anti-Fas treatment

\begin{tabular}{llllll}
\hline Time (hours) & 0 & 1 & 2 & 3 & 4 \\
Viability (\%) & 100 & 100 & $97 \pm 3$ & $86 \pm 7$ & $64 \pm 14$ \\
\hline
\end{tabular}

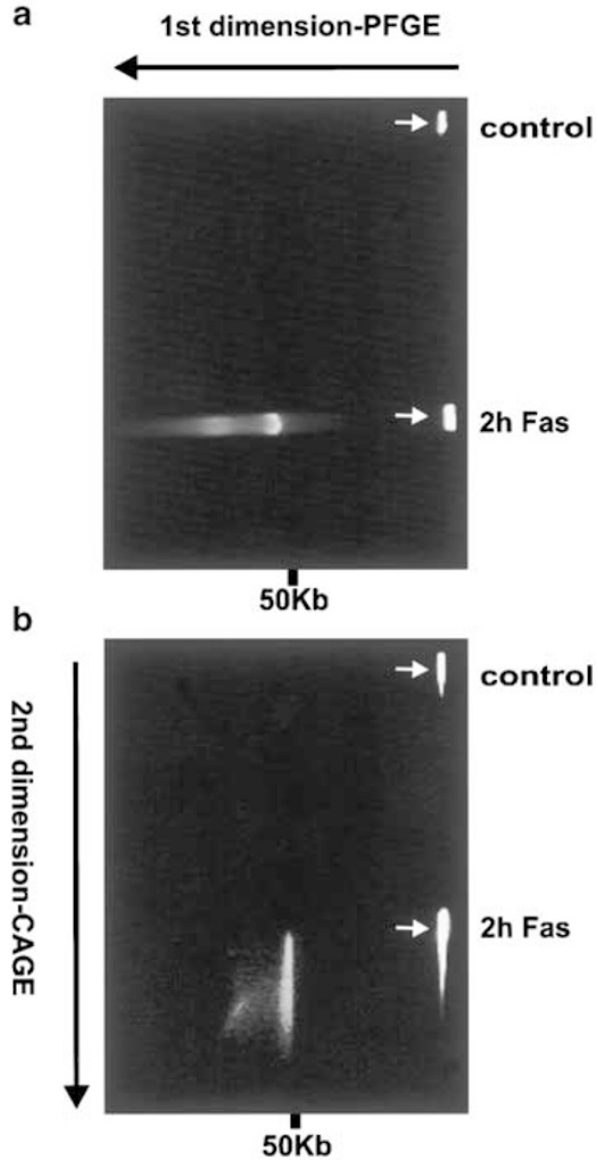

Figure 1 Two-dimensional analysis of DNA fragmentation. DNA from control and $2 \mathrm{~h}$ anti-Fas-treated ( $100 \mathrm{ng} / \mathrm{ml})$ Jurkat cells was processed in agarose plugs and analysed by PFGE in a first dimension (a) and by CAGE in a second dimension (b), as described in the Materials and Methods section

well after the PFGE separation (Figure $1 \mathrm{~b}$, indicated by arrows). There was no significant number of ss DNA breaks in the control sample.

The integrity of the nuclear proteins SATB1, PARP, lamin B and NuMA was assessed by Western blotting (Figure 2) using cells subjected to the same experimental treatment. Although caspase-mediated proteolysis of these proteins during apoptosis has been previously reported, ${ }^{8-11,29}$ this experiment was performed to compare their degradation kinetics with that of DNA. Activation of nuclear proteolysis was evident after $1 \mathrm{~h}$ of anti-Fas treatment (Figure 2, lamin B, NuMA). Within $3 \mathrm{~h}$ of the treatment, all four proteins underwent extensive degradation, producing breakdown products characteristic for each; that is, $65 \mathrm{kDa}$ for SATB1, $85 \mathrm{kDa}$ PARP, $46 \mathrm{kDa}$ for lamin B and 220/ 200 for NuMA. Therefore, at the $2 \mathrm{~h}$ time point when the cells were still viable but the large apoptotic DNA fragments and a significant level of ss DNA breaks were already present (Figure 1), the integrity of the nuclear proteins was also seriously compromised (Figure 2).

\section{Alteration in nuclear SATB1 staining}

We have recently reported that a loss of nuclear SATB1 staining and an associated change in its functionality occurred 

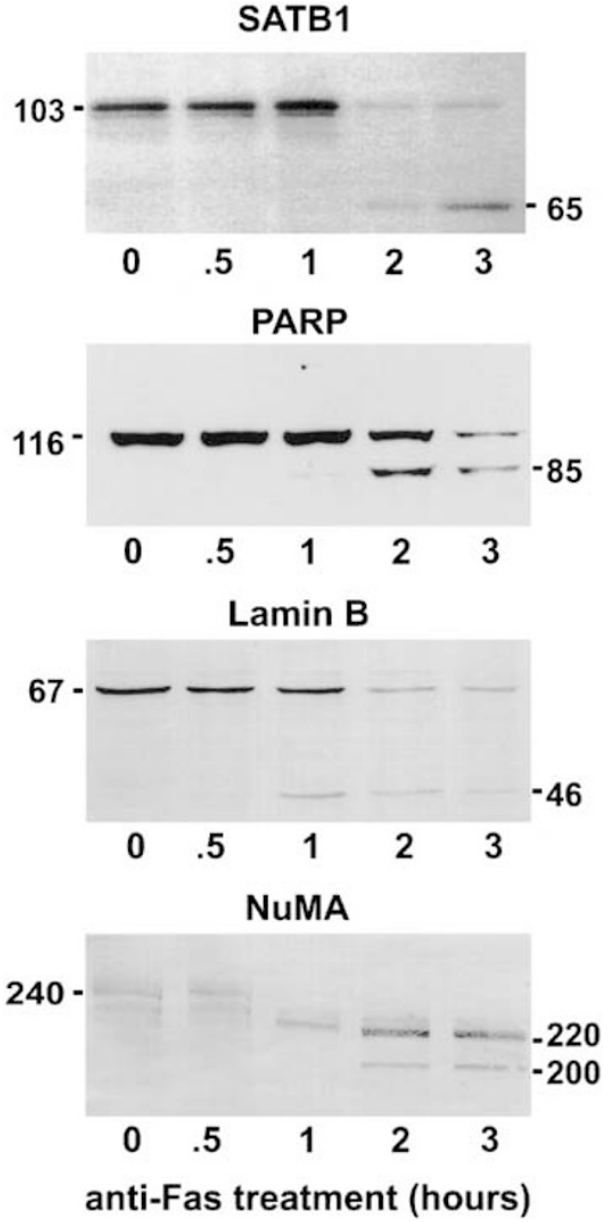

Figure 2 Degradation kinetics of selected nuclear proteins. Cell were treated with anti-Fas for $0,0.5,1,2$ and $3 \mathrm{~h}$, lysed with RIPA buffer and analysed (total cellular proteins) by Western blotting. The molecular weights of the intact proteins and their apoptosis fragments are indicated in $\mathrm{kDa}$

early in thymocyte apoptosis. ${ }^{29}$ Here we report a similar phenomenon in anti-FAS-treated Jurkat cells (Figure 3). In control cells, SATB1 immunostaining was pannucleoplasmic, excluded from nucleoli and confined within the nuclear interior defined by the lamin $B$ staining (Figure $3 a$ and $b$, lamin B - green, SATB1 - red). Following anti-Fas treatment, the cells begin to lose a significant portion of the SATB1 signal, some as early as $30 \mathrm{~min}$ after the treatment (Figure 3c). An increasing proportion of cells passed through this stage by $2 \mathrm{~h}$ of the treatment. This loss of SATB1 signal preceded the collapse of chromatin and the loss of lamina and nuclear envelope structures (Figure 3c, lamin B-green; SATB1 - red). Double labelling of the cells for DNA breaks using terminal deoxynucleotidyl transferase (TdT)-mediated nick and labeling (TUNEL) and SATB1 revealed the existence of DNA breaks prior to the obvious morphological alteration in SATB1 (Figure 3e; TUNEL — green, SATB1 — red); evidently, no such breaks existed in control untreated cells (Figure $3 d$ ). However, the maximal TUNEL labelling was seen in cells that had lost the SATB1 signal almost completely. In these cells any remaining nuclear SATB1 was detected in the remnants of the nucleoplasmic space (Figure $3 f$ ).
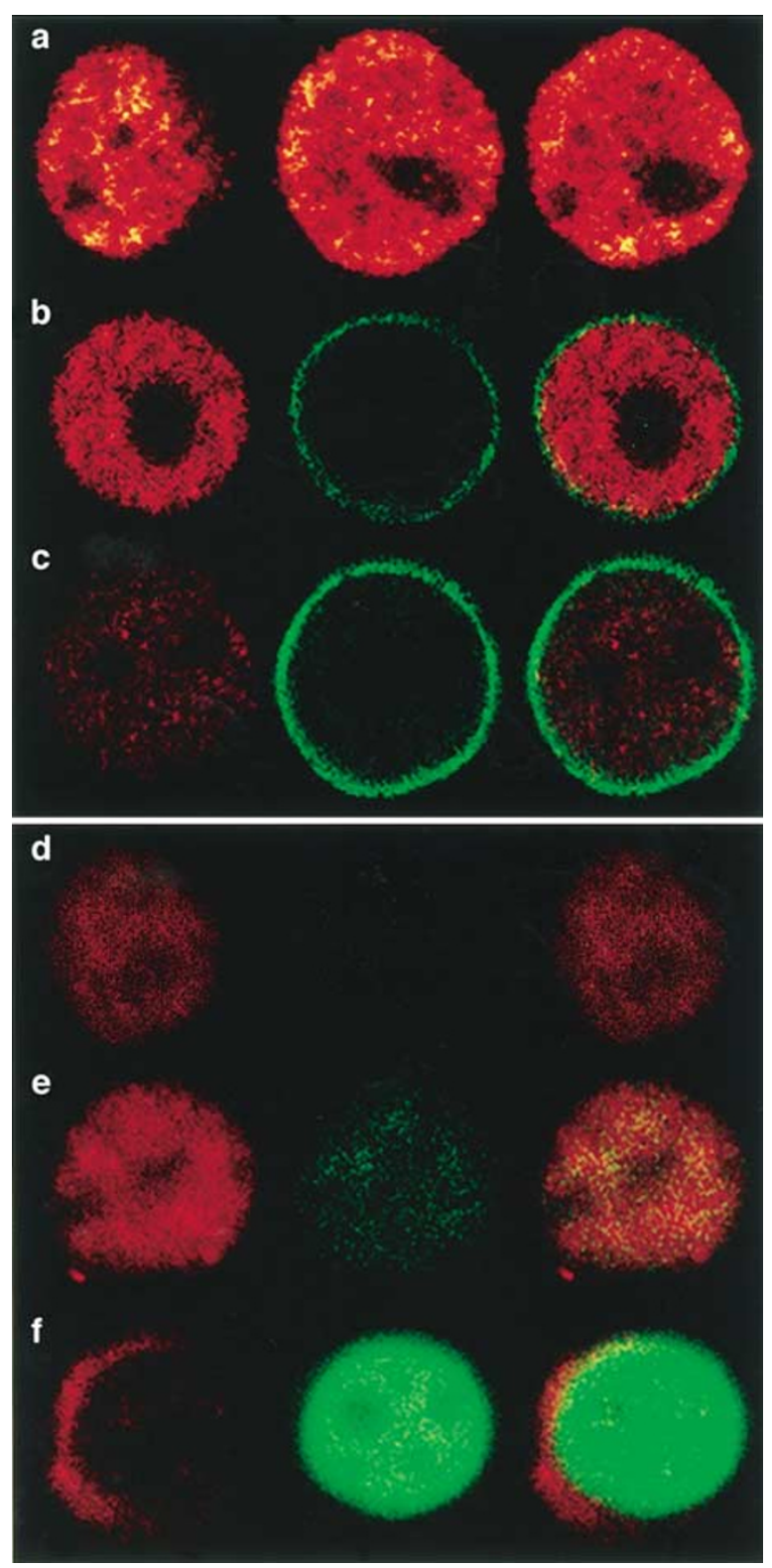

Figure 3 Confocal microscopy images of SATB1 immunostaining and TUNEL labelled DNA breaks. Control cells ( $\mathbf{a}, \mathbf{b}$ and $\mathbf{d})$ and cells treated with anti-Fas for $0.5 \mathrm{~h} \mathrm{(c,e)} \mathrm{and} 2 \mathrm{~h}(\mathrm{f})$ were stained with anti-SATB1 antibody (red signal in all panels) and were double-labelled with antilamin $B$ antibody (b, $\mathbf{c}$; green signal). DNA breaks were labelled by TUNEL after SATB1 staining ( $\mathbf{d}$, $\mathbf{e}$ and $\mathbf{f}$; green signal). Panel $A$ depicts three sections through a representative control nucleus. Panels $b-f$ each depict a single section through a representative nucleus, with the SATB1 signal presented on the left, the lamin B or TUNEL signal in the middle, and the overlay on the right

At this level of detection, NuMA distribution in the control, untreated cells, was very similar to that of SATB1. The signal was distributed throughout the nucleoplasm and was clearly absent from nucleoli (Figure 4a). Although the biochemical alterations of NuMA preceded those of SATB1 (Figure 2), there was no detectable early change in NuMA distribution (Figure 4). Rather, reorganization of NuMA into the remaining nucleoplasmic space was detected concurrently with chromatin collapse and maximal labelling of DNA breaks (Figure 4b). 


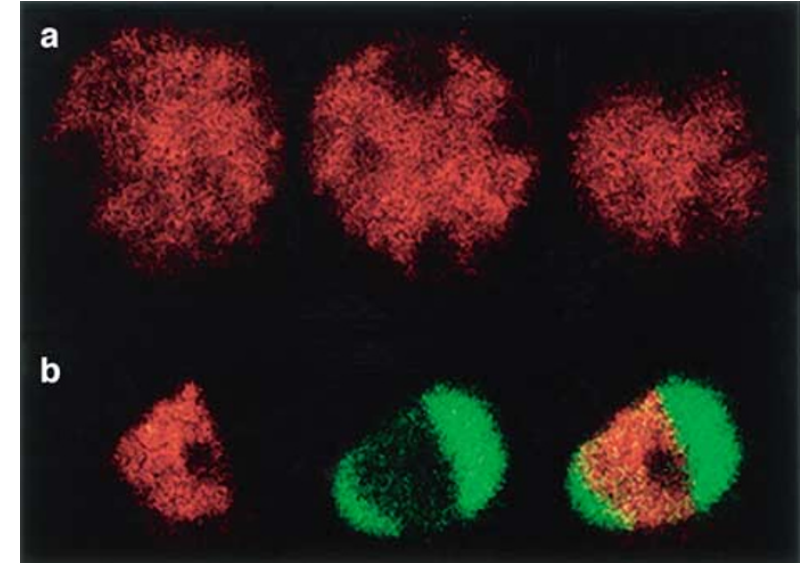

Figure 4 Confocal microscopy images of NuMA immunostaining. Control cells (a) and cells treated with anti-Fas for $2 \mathrm{~h}$ (b) were stained with anti-NuMA antibody (red signal). DNA breaks were labelled by TUNEL after NuMA staining (b, green signal). Panel a depicts three sections through a representative control nucleus. Panel $\mathbf{b}$ depicts a single section through a representative nucleus, with the NuMA signal presented on the left, the TUNEL signal in the middle, and the overlay on the right

\section{Selection of genes containing BUR-like elements}

The appearance of DNA breaks throughout the nucleus concurrent with the loss of SATB1 nuclear staining (Figures 2 and 3 ) implied the existence of numerous SATB1-binding sites in the genome. Indeed, the presence of additional SATB1-binding DNA sequences in vivo has been recently reported. ${ }^{30}$ We have extended this search further, by performing a Blast search of the Genbank database for genomic sequences with a high similarity to the wellcharacterized $25 \mathrm{bp}$ BUR sequence of the mouse IgH gene. We selected five human genes that contained a short AT-rich sequence highly similar to the bona fide SATB1-binding BUR site. They are listed in Table 2 . These clusters of ATC were typically present on one DNA strand in the noncoding regions, consistent with the context of the core BUR element. Synthetic complementary oligonucleotides were used to demonstrate the ability of these sequences to bind nuclear proteins in two in vitro assays, EMSA and SW hybridization (Figure 5). The binding of the IgH enhancer BUR site is shown in Figure $5 \mathrm{a}-\mathrm{C}$ and the binding of a putative BUR-like site of the c-myc gene in Figure $5 \mathrm{~d}$ and e. Under the EMSA conditions, both probes, IgH (Figure 5a) and c-myc (Figure $5 d$ ), formed protein complexes when incubated with nuclear proteins from control cells (lane 1 in both panels). Furthermore, there was also a significant decrease in the intensity of the retarded bands in the $2 \mathrm{~h}$ anti-Fas-treated samples, indicating a loss of DNA-binding activity (lane 2 in Figure $5 a$ and d), coinciding with the advanced proteolytic degradation of nuclear proteins at this time point (Figure 2). SW blotting was also performed to establish the molecular identities of the protein(s) interacting with these sequences (Figure $5 \mathrm{~b}, \mathrm{c}$ and e). Typically, the BUR site of the $\mathrm{IgH}$ gene labelled a single protein of approximately $103 \mathrm{kDa}$, shown previously to be SATB1 $1 .{ }^{29}$ However, if the gels were subjected to a renaturation step in $4 \mathrm{M}$ urea to remove SDS following the PAGE and prior to protein electrotransfer, not
Table 2 Alignment of the SATB1-binding site with BUR-like sequences selected from the Genbank

\begin{tabular}{|c|c|}
\hline IgH & TСТTTААТTТСТААТАТАТTТАGАА \\
\hline \multirow[t]{2}{*}{ HMG } & ТTСТАААТАТАТСАТААААТТА-AG \\
\hline & 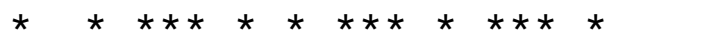 \\
\hline IgH & 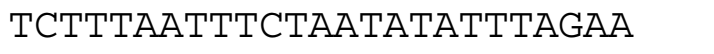 \\
\hline \multirow[t]{2}{*}{ MYC } & TTTTT- - - TTCTATTGTTTTTAGAA \\
\hline & 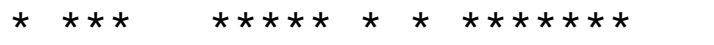 \\
\hline IgH & TСТTTААТTТСТААТАТАТTТАGАА \\
\hline \multirow[t]{2}{*}{ PRM } & - - - ТTAАТтTСТААТСТTТTТАСАА \\
\hline & 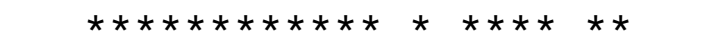 \\
\hline IgH & TСТTTAАТTTСТААТАTATTTAGAА \\
\hline \multirow[t]{2}{*}{$\mathrm{PDH}$} & TTTCС- - TTTСТАATATATT-AAGA \\
\hline & 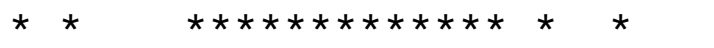 \\
\hline IgH & ТСТTТААТTТСТААТАТАТTТАGАА \\
\hline \multirow[t]{2}{*}{ RCL } & TGTTСААТTTСТААТАТАT - - AGAG \\
\hline & 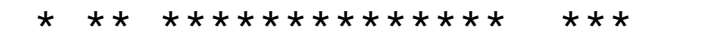 \\
\hline \multicolumn{2}{|c|}{$\begin{array}{l}\text { IgH: mouse germline IgH heavy chain gene (accession number J00440, sequence located in } 3^{\prime} \\
\text { enhancer, at 2608-2632); HMG: human high-mobility group phosphoprotein gene (accession } \\
\text { number L41044, sequence located in intron } 2 \text { at } 12468-12488) ; \text { MYC: human c-myc proto- } \\
\text { oncogene (accession number J00120, sequence located in } 3^{\prime} \text { UTR at 7627-7647); PRM: human } \\
\text { protamine 1, protamine } 2 \text { and transition protein genes (accession number U15422, sequence } \\
\text { located in } 5^{\prime} \text { upstream at } 10233-10253 \text { ); PDH: Human pyruvate dehydrogenase alpha subunit } \\
\text { gene (accession number D90084, sequence located in intron } 5 \text { at } 10320-10340 \text { ); RCL: Human } \\
\text { red cell type low molecular weight acid phosphatase gene (accession number U25847, sequence } \\
\text { located in intron } 4 \text { at 9780-9800). }\end{array}$} \\
\hline
\end{tabular}

only was the binding of the probe to SATB1 more efficient, but an additional band of approximately $60 \mathrm{kDa}$ was also clearly labelled by the probe (Figure $5 \mathrm{c}$ ). The identity of this protein is unknown at present. The same effect of the gel renaturation step was true for the c-myc probe, and the results shown in Figure $5 \mathrm{e}$ were obtained from a renatured gel. The c-myc probe recognized and labelled two protein bands and the probe binding to the smaller protein of approximately $60 \mathrm{kDa}$ seemed significantly stronger than that to the larger one of approximately $103 \mathrm{kDa}$, as judged by the band intensities. These protein-binding interactions were also altered in the $2 \mathrm{~h}$ anti-Fas samples (lane 2, Figure $5 \mathrm{c}$ and e). The labelling intensities of both the 103 and $60 \mathrm{kDa}$ bands were markedly reduced and, in the case of the c-myc probe, an additional protein band of approximately $45 \mathrm{kDa}$ appeared in parallel (Figure 5e, lane 2). Combined, the data presented in Figure 5 showed a loss of protein(s) capable of binding to BUR regions in Jurkat cells undergoing Fas-induced apoptosis.

\section{Genome integrity in the proximity of BUR-like sequences}

We employed PCR amplification of genomic DNA to examine the intactness of the genome in the proximity of these putative 


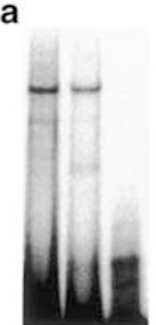

123 b

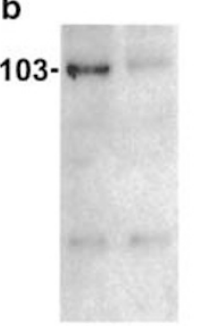

12
C

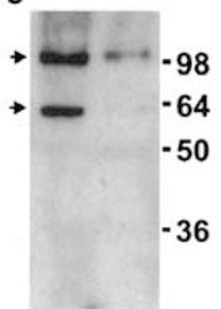

12 d

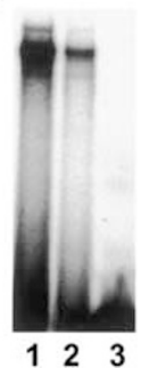

\begin{abstract}
e
\end{abstract}

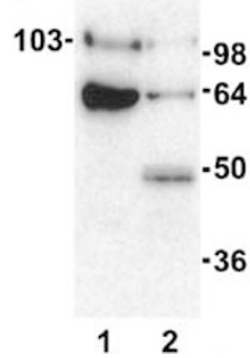

Figure 5 Anti-Fas-induced changes in DNA-binding proteins. Nuclear proteins from control and $2 \mathrm{~h}$ anti-Fas-treated cells were used in the EMSA ( $a$ and $\mathbf{d}$ ) and SW hybridization ( $\mathbf{b}, \mathbf{c}$ and $\mathbf{e}$ ) assays, as described in the Materials and Methods section. The SW hybridization was performed without (b) or with the urea renaturation step (c and $\mathbf{e}$ ). The $25 \mathrm{bp}$ sequence from the $\operatorname{lgH}$ gene $(\mathbf{A}-\mathbf{C})$ and $22 \mathrm{bp}$ sequence from the c-myc gene ( $\mathbf{d}$ and $\mathbf{e}$ ) were radiolabelled and used as probes (Table 2). Lane 1: control protein extract; lane 2: protein extract from $2 \mathrm{~h}$ anti-Fas-treated cells; lane 3: free radiolabelled probe. The positions of prestained protein size markers are indicated in $\mathrm{kDa}$

BUR sites (Table 3 ). The analysis was performed on total genomic DNA isolated from both control, untreated Jurkat cells and cells treated with anti-Fas for $2 \mathrm{~h}$ (Figure 6 ). For each gene, primers were designed to amplify both the region spanning the BUR-like element (Figure 6a, primers CS and $\mathrm{CP}$ ) and the adjacent sequences outside these sites (primers OS and OP, Figure 6a). All primers used for PCR amplifications are listed in Table 3. Using primers spanning the BUR sites, we consistently obtained more PCR product from the control than from the $2 \mathrm{~h}$ anti-Fas-treated samples for all five genes examined (compare lanes 1 and 2 in all panels). On the other hand, the outside primers amplified equal amounts of PCR product in both DNA samples (compare lanes 3 and 4 in all panels).

\section{Detection and mapping of ss DNA breaks by LM-PCR}

The inability to amplify equal amounts of PCR product from control and apoptotic DNA with primers spanning the BUR sites clearly pointed out that the integrity of these sites was compromised. The question was whether DNA breaks were generated in the proximity of these sites. To establish this, we applied the LM-PCR method to amplify all DNA fragments from the gene-specific primers (SGSPs and GSPS) to any break point present on the DNA strand, as described in the Materials and Method section and outlined in the schematic diagram shown in Figure 7. All primers used for LM-PCR are listed in Table 3. The results presented in Figures 8 and 9 show radiolabelled band patterns, each band representing one SS break in the analysed DNA samples. These bands were much weaker or completely absent in the control DNA samples (compare lanes 1 -control and lanes $2-2 \mathrm{~h}$ anti-Fas). We have detected multiple DNA breaks in each of the genes analysed (Figures 8 and 9a). The presence of the breaks on the antisense DNA strand was also examined, since the break accumulation at the same position on both strands would produce a de facto double-strand (ds) break. As shown in Figure $9 \mathrm{~b}$, bands representing multiple breaks were also observed on the antisense DNA strand.

We also performed LM-PCR with T4 polynucleotide kinasetreated DNA to establish the nature of the strand ends (Figure 9c). Since the synthetic linker adapter used for the LMPCR does not contain a phosphate group on either end, the $5^{\prime}$ end of the genomic DNA must carry a phosphate group; otherwise, the ligation would not take place and PCR amplification would not proceed. We have obtained the same LM-PCR band pattern from both kinase-treated and untreated genomic DNA (Figure 9a and c), indicating the presence of phosphate groups on the $5^{\prime}$ DNA ends.

The exact position of each break was calculated according to the size of each band, which was determined by running a known DNA sequencing reaction alongside the radiolabelled LM-PCR products. For two of the studied genes, c-myc and HMG, we have mapped the positions of all detected breaks on both DNA strands, relative to each other and to the putative BUR protein-binding site. The results are presented graphically in Figure 10. Most of the breaks were single stranded, generated by a nuclease without sequence specificity. Frequently, the breaks on opposite strands were as close as one or two base pairs apart, which would result in the generation of double-stranded fragments. The cleavage was detected more frequently at certain sites, as evidenced by a higher intensity of these bands. These are indicated by asterisks in Figures $9 \mathrm{a}, \mathrm{b}$ and $10 \mathrm{a}, \mathrm{b}$. The distance between the cleavage sites showed no apparent pattern. Breaks were found both inside the putative core BUR sequence and as far as 200 bp away from it.

\section{Discussion}

It is generally accepted that proteolysis of nuclear proteins plays a role in the collapse of nuclear structure and compartmentalization of the nuclear remnants into apoptotic bodies during the final stages of apoptosis. ${ }^{31}$ However, in many cell types undergoing apoptosis in response to a variety of agents, the degradation of nuclear matrix proteins, most notably those involved in the maintenance of normal chromatin structure, can be detected concurrently with HMW DNA cleavage and before ultimate nuclear collapse, ${ }^{11,25,29,32}$ suggesting that these two degradative processes are interlinked. The data presented in this manuscript are consistent with this statement, since the proteolysis of NuMA, lamin B, PARP and SATB1 and the appearance of both ss and ds DNA breaks in anti-Fas-treated Jurkat cells were detected simultaneously and prior to the detectable loss 
Table 3 List of PCR and LMPCR primersGene

\begin{tabular}{|c|c|c|}
\hline & Primer sequence & Position \\
\hline \multirow[t]{3}{*}{$\begin{array}{l}\text { HMG } \\
\text { BamHI }\end{array}$} & $\begin{array}{l}\text { CS: } 5^{\prime} \text { GTGAACACCTCCTGTAACACG } 3^{\prime} \\
\text { CP: } 5^{\prime} \text { ATCAAGAGAGAAAAGGGAGATATGGTCGG } 3^{\prime} \\
\text { PCR product: } \mathbf{3 8 7} \mathbf{b p}\end{array}$ & $\begin{array}{l}12272-12292 \\
12629-12658\end{array}$ \\
\hline & $\begin{array}{l}\text { OS: } 5^{\prime} \text { AAGACAGGGCACCATCACAC } 3^{\prime} \\
\text { OP: } 5^{\prime} \text { TGCCTGACAAAAGCTATGGC } 3^{\prime} \\
\text { PCR product: } 638 \text { bp }\end{array}$ & $\begin{array}{l}10966-10985 \\
11584-11603\end{array}$ \\
\hline & $\begin{array}{l}\text { SGSP1: 5' GTGAACACCTCCTGTAACACG 3' } \\
\text { SGSP2: 5' TGCAGTACATTGAAGAGCCTGGAG } 3^{\prime} \\
\text { SGSP3: } 5^{\prime} \text { GCAGTACATTGAAGAGCCTGGAGTACAG } 3^{\prime} \\
\text { GSP1: } 5^{\prime} \text { ACATTAGCTGTGCTGTGTGGCG } 3^{\prime} \\
\text { GSP2: } 5^{\prime} \text { CACATCAAGAGAGAAAAGGGAGATATGG } 3^{\prime} \\
\text { GSP3: } 5^{\prime} \text { ATCAAGAGAGAAAGGGAGATATGGTCGG } 3^{\prime}\end{array}$ & $\begin{array}{l}12272-12292 \\
12374-12397 \\
12375-12402 \\
13016-13037 \\
12633-12660 \\
12629-12658\end{array}$ \\
\hline \multirow[t]{3}{*}{$\begin{array}{l}\text { MYC } \\
\text { Xhol, Bgll/II }\end{array}$} & $\begin{array}{l}\text { CS: } 5^{\prime} \text { ACTTGTTGCGGAAACGACGAG } 3^{\prime} \\
\text { CP: } 5^{\prime} \text { ATGCTTAGGAGTGCTTGGGAC } 3^{\prime} \\
\text { PCR product: } 1297 \mathrm{bp}\end{array}$ & $\begin{array}{l}7149-7169 \\
8425-8445\end{array}$ \\
\hline & $\begin{array}{l}\text { OS: } 5^{\prime} \text { GATGGGGTTTCATCGTGTTG } 3^{\prime} \\
\text { OP: } 5^{\prime} \text { AGACGTTGTGTGTTCGCCTC } 3^{\prime} \\
\text { PCR product: } \mathbf{5 7 8} \mathbf{b p}\end{array}$ & $\begin{array}{l}6403-6422 \\
6980-6961\end{array}$ \\
\hline & $\begin{array}{l}\text { SGSP1: 5' ACTTGTTGCGGAAACGACGAG } 3^{\prime} \\
\text { SGSP2: 5' CCTCACAACCTTGGCTGAGTCTTGA 3' } \\
\text { SGSP3: 5' CCTCACAACCTTGGCTGAGTCTTGAGAC 3' } \\
\text { GSP1: 5' ATGCTTAGGAGTGCTTGGGAC } 3^{\prime} \\
\text { GSP2: 5' TCCTTTGCCTACCTCTCACCTTCTC 3' } \\
\text { GSP3: 5' TCCTTTGCCTACCTCTCACCTTCTCACC }\end{array}$ & $\begin{array}{l}7149-7169 \\
7303-7327 \\
7303-7330 \\
8425-8445 \\
7921-7945 \\
7918-7945\end{array}$ \\
\hline \multirow[t]{3}{*}{$\begin{array}{l}\mathrm{PRM} \\
\mathrm{Bg} / \mathrm{I} / \mathrm{II}\end{array}$} & $\begin{array}{l}\text { CS: } 5^{\prime} \text { GGGATCCTGGAACAGGAAAAC } 3^{\prime} \\
\text { CP: } 5^{\prime} \text { GCCACAATTCCATAGTCAGGG } 3^{\prime} \\
\text { PCR product: } 1401 \text { bp }\end{array}$ & $\begin{array}{l}9138-9159 \\
10518-10538\end{array}$ \\
\hline & $\begin{array}{l}\text { OS: } 5^{\prime} \text { GTCTTTCCTTGAACAGGGCG 3' } \\
\text { OP: } 5^{\prime} \text { TCGTCTGGGATCTTGAAGCC } 3^{\prime} \\
\text { PCR product: } 547 \text { bp }\end{array}$ & $\begin{array}{l}10679-10698 \\
11225-11206\end{array}$ \\
\hline & $\begin{array}{l}\text { SGSP1: } 5^{\prime} \text { GGGATCCTGGAACAGGAAAAC } 3^{\prime} \\
\text { SGSP2: 5' TTAACAATCGGGGAGACTGGGACAC } 3^{\prime} \\
\text { SGSP3: 5' TTAACAATCGGGGAGACTGGGACACTGG } 3^{\prime} \\
\text { GSP1: 5' GCCACAATTCCATAGTCAGGG } 3^{\prime} \\
\text { GSP2: } 5^{\prime} \text { GCGTGTTCATACAGGTGTGAGATGG } 3^{\prime} \\
\text { GSP3: } 5^{\prime} \text { GCGTGTTCATACAGGTGTGAGTGGAGG } 3^{\prime}\end{array}$ & $\begin{array}{l}9138-9159 \\
9438-9463 \\
9438-9466 \\
10518-10538 \\
10470-10494 \\
10467-10494\end{array}$ \\
\hline \multirow[t]{3}{*}{$\begin{array}{l}\text { PDH } \\
\text { Pstl }\end{array}$} & $\begin{array}{l}\text { CS: } 5^{\prime} \text { GGATCGATGCACATGTATGCC } 3^{\prime} \\
\text { CP: } 5^{\prime} \text { CCCTATCTCTCTGTTTATCCCACCT } 3^{\prime} \\
\text { PCR product: } 1248 \text { bp }\end{array}$ & $\begin{array}{l}9532-9552 \\
10921-10941\end{array}$ \\
\hline & $\begin{array}{l}\text { OS: } 5^{\prime} \text { TAAAGGACCTCCCCACAACC } 3^{\prime} \\
\text { OP: } 5^{\prime} \text { CTGCCGCTCTCTCAACAGAC } 3^{\prime} \\
\text { PCR product: } 621 \text { bp }\end{array}$ & $\begin{array}{l}11255-11274 \\
11875-11856\end{array}$ \\
\hline & $\begin{array}{l}\text { SGSP1: 5' GGATCGATGCACATGTATGCC } 3^{\prime} \\
\text { SGSP2: 5' ACTATACAGCCTAGGTGTGCAGTGG } 3^{\prime} \\
\text { SGSP3: } 5^{\prime} \text { ACTATACAGCCTAGGTGTGCAGTGGGCT } 3^{\prime} \\
\text { GSP1: } 5^{\prime} \text { TACAGGCTAGAGCAATCCCAG } 3^{\prime} \\
\text { GSP2: 5' CCCTATCTCTCTGTTTATCCCACCT } 3^{\prime} \\
\text { GSP3: } 5^{\prime} \text { CCCTATCTCTCTGTTATCCCACCTCCG } 3^{\prime}\end{array}$ & $\begin{array}{l}9532-9552 \\
9906-9930 \\
9906-9933 \\
10921-10941 \\
10751-10779 \\
10748-10779\end{array}$ \\
\hline \multirow[t]{3}{*}{$\begin{array}{l}\mathrm{RCL} \\
B g / \mathrm{I} / \mathrm{II}\end{array}$} & $\begin{array}{l}\text { CS: } 5^{\prime} \text { TCGATCACCCATTGCAGAAGC } 3^{\prime} \\
\text { CP: } 5^{\prime} \text { CAGCAGGATGATTACTATGGCC } 3^{\prime} \\
\text { PCR product: } 753 \text { bp }\end{array}$ & $\begin{array}{l}9339-9359 \\
10070-10091\end{array}$ \\
\hline & $\begin{array}{l}\text { OS: } 5^{\prime} \text { GCTTTCCTGAGTTTGGGGAG } 3^{\prime} \\
\text { OP: } 5^{\prime} \text { AGCTGGTTCAGGACACCCTC } 3^{\prime} \\
\text { PCR product: } 536 \text { bp }\end{array}$ & $\begin{array}{l}8386-8405 \\
8921-8902\end{array}$ \\
\hline & 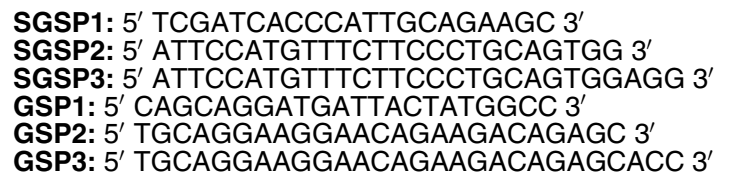 & $\begin{array}{l}9339-9359 \\
9476-9500 \\
9476-9503 \\
10070-10091 \\
10025-10049 \\
10022-10049\end{array}$ \\
\hline
\end{tabular}

of cell viability. This raised the question of whether the proteolysis of a specific subset of nuclear proteins, such as BUR-binding proteins, could contribute to the accessibility of these sites to endonuclease(s). Indeed, while we detected site-specific cleavage of NuMA, lamin B, PARP and SATB1 (Figure 1), examination of these antigens at the single cell level by confocal microscopy revealed that only the morphological reorganization of the BUR-binding SATB1 protein 


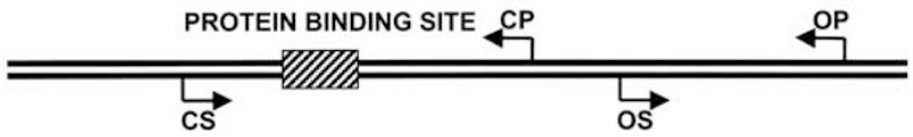

b

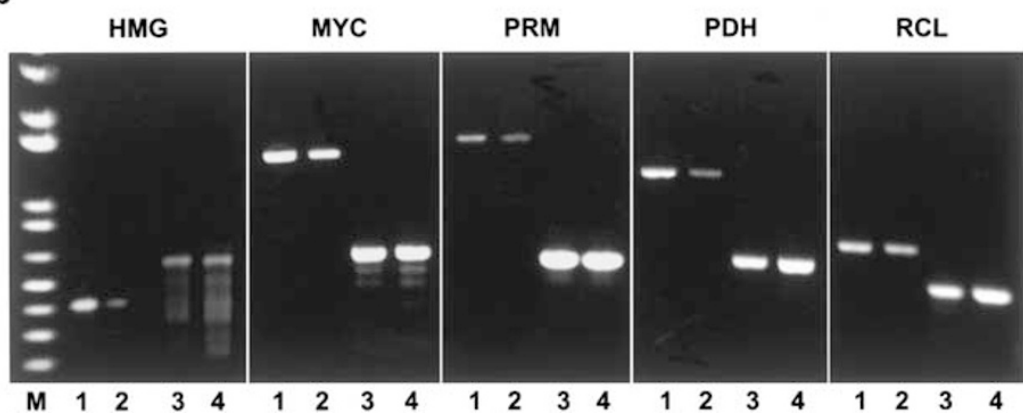

Figure 6 Amplification of genomic DNA by conventional PCR. ( a) Relative positions of primers used for conventional PCR. The solid line represents DNA strands; the hatched box indicates protein-binding site; arrows illustrate the direction and relative positions of the PCR primers. ( $b$ ) Ethidium-bromide-stained agarose gel of the conventional PCR products. For each gene tested, lanes 1 and 2 show the PCR products obtained using the CS and CP primers spanning a putative protein-binding site, while lanes 3 and 4 feature the PCR products obtained using the OS and OP primers outside the protein-binding sites. The primer sequences are listed in Table 3. Lanes 1 and 3: genomic DNA isolated from control untreated cells; lanes 2 and 4: genomic DNA isolated from $2 \mathrm{~h}$ anti-Fas-treated cells; M: molecular size marker

occurred prior to nuclear collapse and concurrently with the initial DNA cleavage (Figures 3 and 4). This is consistent with the recent study of Galande et al. ${ }^{29}$ which showed that the SATB1-DNA interaction has been fundamentally altered early in the apoptotic process. This is because caspase-6-mediated SATB1 cleavage separates its DNA-binding domains from a PDZ domain, which is involved in protein dimerization. SATB1 in its monomeric form is unable to bind to DNA. ${ }^{29,33}$ Another MAR-binding protein, SAF-A, is also cleaved during apoptosis and loses its DNA-binding capacity, although in this case the cleavage occurs within the DNA-binding domain. ${ }^{34}$

There have been a number of reports in the literature suggesting that initiation of apoptotic DNA cleavage occurs at matrix attachment regions. ${ }^{6,7,35-37}$ The first supporting evidence came from studies that establish that high molecular weight DNA fragments of 50 and $300 \mathrm{~kb}$, produced in early stages of apoptosis, represent structural domains of chromatin, loops and rosettes, respectively. ${ }^{1,7}$ It was then suggested that topoisomerase $\mathrm{II}$, located at matrix attachment sites, is responsible for this cleavage since inhibition of its activity generated the same pattern of DNA fragments. ${ }^{6,38}$ However, others have shown that the activation of endogenous and several exogenous nucleases also results in DNA digestion in the proximity of MARs and produces similar sets of high molecular weight 50 and $300 \mathrm{~kb}$ fragments as those generated by topoisomerase II inhibitors. ${ }^{7,36}$ More direct evidence that MARs are specific targets for early DNA cleavage came recently from the study of Khodarev et al. ${ }^{39}$ These authors performed a directional cloning of DNA ends corresponding to high molecular weight chromatin fragments produced during radiation-induced apoptosis, and found them to contain ATrich MAR-like sequences.

This vulnerability of MARs to endonucleolysis might stem from either their unique and nuclease-accessible secondary structure or, alternatively, it might be due to the compromised functionality of the nuclear matrix, particularly its DNA-binding components. Our results and those of others ${ }^{11,25,29,32}$ support the latter model. Indeed, the proteolytic process activated during apoptosis targets many nuclear matrix proteins, disrupts normal interactions between MAR sequences and MAR-binding proteins, and could render DNA at these sites vulnerable to the initial cleavage events. Thus, MAR-binding proteins protect DNA from endonucleases, and only when their integrity is altered during the apoptotic process is the exposed DNA cleaved. Additional supporting evidence for this claim comes from the study of Peitsch et al., ${ }^{4}$ who reported earlier that single-stranded DNA cuts during apoptosis are much less frequent in DNA wrapped around core histones than in the linker region. In addition, the study of Cairns and Murray $^{40}$ showed that the interaction between DNA and transcription factors also protects DNA from the effects of DNA-damaging agents. Although both these studies relate to oligonucleosomal DNA cleavage, they support the notion that DNA-protein interactions protect DNA from degradation.

Although MARs have been identified as the genomic regions targeted by nucleases in apoptosis, it is not known exactly where these initial DNA cleavage events occur. The cleavage sites have not been precisely mapped, due to a significant heterogeneity in MAR sequence and size as well as errors in sizing the apoptotic DNA fragments which, under the PFGE resolution, could be several kilobases. ${ }^{7,36,37}$ Our approach was to use LM-PCR to map precisely the cleavage sites in the genomic sequences selected based on their high similarity to the SATB1-binding site sequence within the $\lg \mathrm{H}$ gene enhancer region, their base content (i.e., A+T-rich, clustering of ATC exclusively on one strand) and location in noncoding regions of the genome. These features are considered to be characteristic for the core-unwinding element of BURs. ${ }^{15,21,22}$ Although we do not have direct proof for their BUR function in vivo, published data show that the putative BUR elements of c-myc and PRM gene cluster 


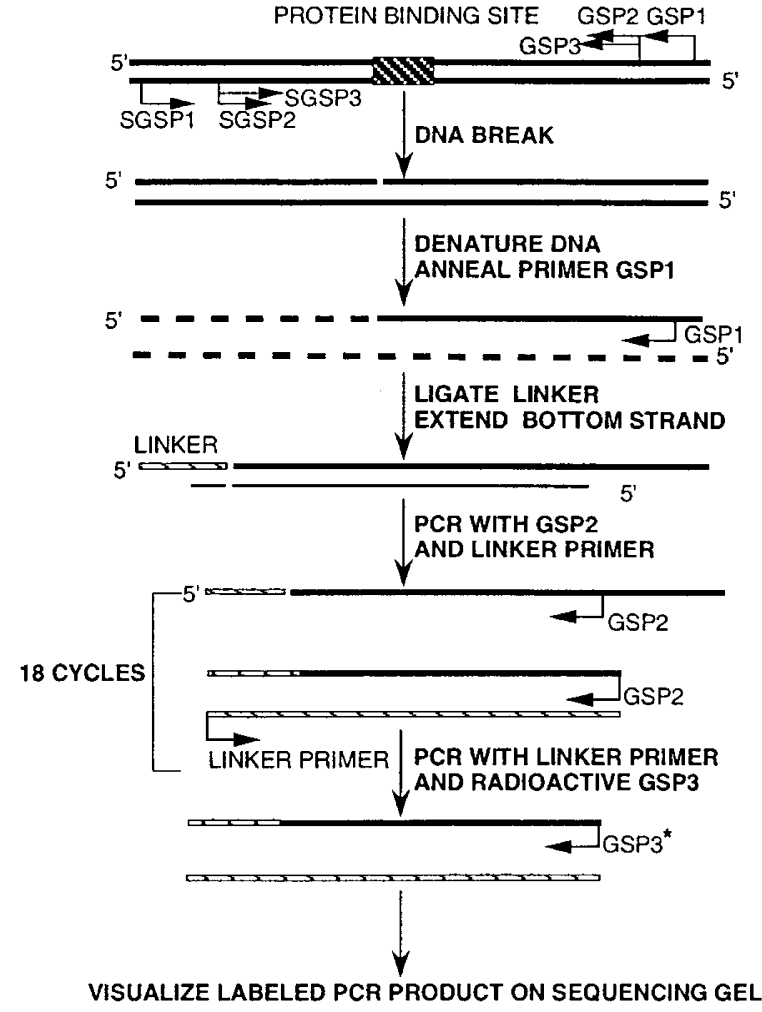

Figure 7 Schematic outline of the LM-PCR procedure. The first gene-specific primer GSP1 was extended with Vent DNA polymerase. The ds blunt end DNA was then ligated with the staggered linker DNA. The first round PCR was performed by extending the newly synthesized first strand DNA to displace the short-strand linker DNA with Taq DNA polymerase, so that this strand could be a part of the rest of the PCR reaction. A total of 18 cycles of PCR was completed after adding GSP2 and linker primers to the reaction, and the final PCR cycle was done by adding a $\left[{ }^{32} \mathrm{P}\right]$-labelled GSP3 primer into the reaction. The radiolabelled PCR products were visualized on a polyacrylamide DNA sequencing gel. The solid lines represent DNA strands; dashed lines indicate DNA strands that no longer form part of the reaction; the short hatched bar shows the linker adapter strand that is actually ligated to the genomic DNA; the long hatched bar denotes the newly synthesized DNA strand

were present within previously identified MAR regions. The PRM sequence was located among several consecutive ALU repeat units and in close proximity to the MAR sequence, ${ }^{17,41}$ and the c-myc sequence was within the identified MAR and next to the p25 protein binding site described by Chou et al. ${ }^{42}$ We have established, however, using in vitro assays, EMSA and SW hybridization that all these sequences were capable of protein binding. This binding was decreased in cells undergoing apoptosis (Figure 5). Furthermore, conventional PCR analysis of genomic DNA fragments containing these putative protein-binding sites revealed that these regions were under-represented in DNA samples from apoptotic cells (Figure 6). Therefore, if the protective DNA-binding proteins, such as SATB1, were degraded, these sites were likely to be targeted by endonuclease(s).

A close analysis of the cleavage sites revealed that the endonuclease, which produced these ss breaks, had no sequence specificity; the cuts were introduced irregularly and produced the characteristic for apoptosis $5^{\prime}-\mathrm{P}$ and $3^{\prime}-\mathrm{OH}$ DNA ends. From this, we concluded that it was not the base

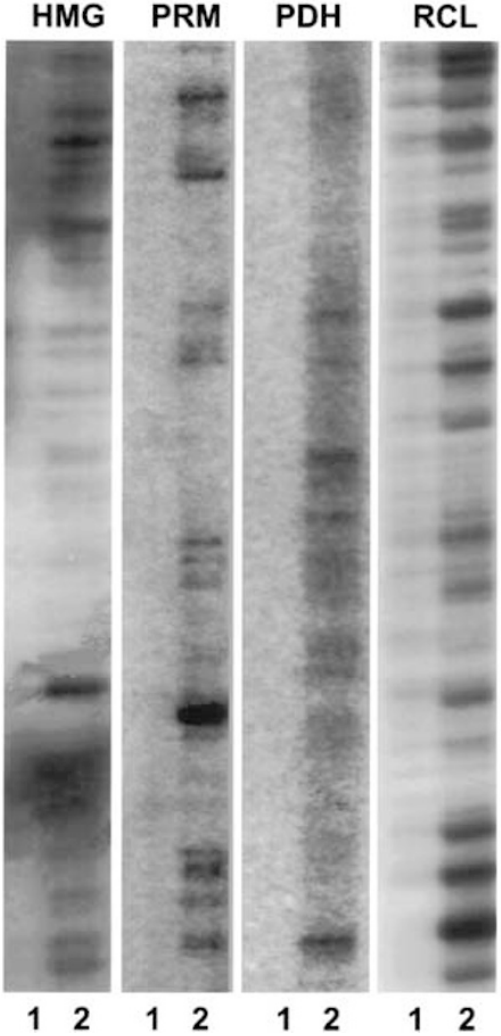

Figure 8 Detection of multiple ss breaks in selected genomic sequences. LMPCR products from four different genes, HMG, PRM, PDH and RLC, obtained using the GSP set of primers, which detected DNA breaks on the sense strand. Each band represents one ss DNA break. The size of each band was determined based on the known DNA sequencing reaction run alongside the radiolabelled LM-PCR (not shown). Lane 1: control, lane 2: $2 \mathrm{~h}$ anti-Fas-treated cells

composition of BURs that determined the cutting sites, but rather the loss of proteinaceous protection permitting increased accessibility of the DNA to endonuclease(s) that was the critical factor.

The identity of the endonuclease responsible for this event is not known. However, considering the fact that this is an early event in the apoptotic process, it is likely that it was carried out by an enzyme constitutively present in the nuclei. Although both acidic DNasell and neutral DNasel are capable of digesting DNA at MARs in permeabilized cells, ${ }^{36}$ neither DNasell nor DNasel are nuclear enzymes. A more likely candidate might be the DNasel-like nuclease described in the literature as DNaseY/DNase $\gamma /$ LS-DNase/DNA1IL3, ${ }^{43-46}$ which we have found constitutively expressed in many cell types and tightly bound to chromatin. This enzyme is capable of generating both ss and ds DNA breaks. A contribution of the CAD/ICAD nuclease system (DFF40/DFF45) to the degradation process cannot be completely ruled out, ${ }^{47}$ although its role in the generation of apoptotic HMW DNA fragments is somewhat controversial. For example, the absence of HMW DNA cleavage was reported in ICAD/DFF45-deficient mouse fibroblasts undergoing apoptosis in response to TNF and in staurosporine-treated Jurkat cells expressing caspase-resistant ICAD/DFF $45 .^{48,49}$ In contrast, targeted disruption of the 


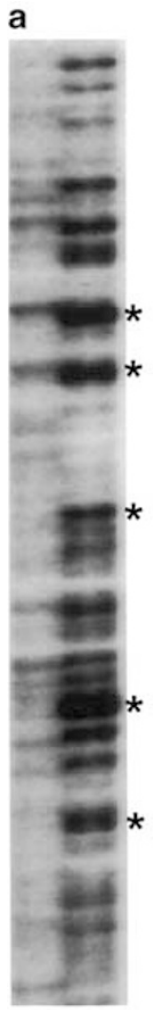

12 b

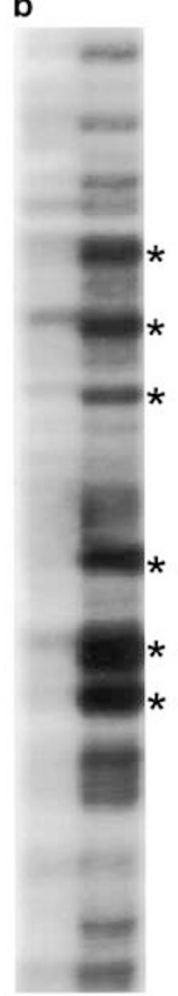

12
C

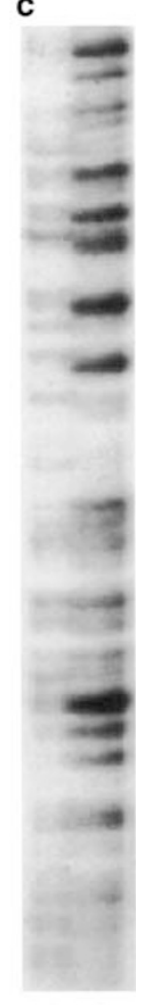

12
Figure 9 Detection of ss breaks in the c-myc gene. (a) LM-PCR products from the MAR-binding region of c-myc obtained using the GSP set of primers, which detected DNA breaks on the sense strand. (b) LM-PCR products from the MARbinding region of c-myc obtained using the SGSP set of primers, which detected DNA breaks on the antisense strand. (c) LM-PCR products obtained from the cmyc GSP primers using genomic DNA treated with $\mathrm{T} 4$ polynucleotide kinase prior to the linker adaptor ligation. Asterisks highlight the DNA breaks, which were detected more frequently and were represented by a more intense band on the autoradiographs. Lane 1: results from the control; lane 2: from $2 \mathrm{~h}$ anti-Fastreated cells

CAD/DFF40 gene (deletion of the entire reading frame) in chicken DT40 cells, treated with etoposide or staurosporine affected only oligonucleosomal but not HMW DNA degradation. 50

In conclusion, although both proteolysis and endonucleolysis are responsible for nuclear destruction in apoptosis, it seems that protease-mediated early degradation of a specific subclass of DNA-binding proteins, such as the BURbinding protein, increases the accessibility of endonuclease(s) to these conformationally unstable DNA sequences. Initially, this results in the generation of ss breaks and, subsequently, to ds DNA fragmentation. The existence of ss breaks in apoptotic DNA fragments has been clearly demonstrated (Figure 1). ${ }^{7,51,52}$ The rate of nuclear proteolysis might also be a factor determining the extent of DNA fragmentation, since rapid protein degradation and collapse of nuclear structure might stop DNA cleavage at any given stage. This would explain the fact that DNA degradation never proceeds to completion and that the DNA ladder is not always observed even in cells containing nucleases capable of internucleosomal DNA cleavage.

\section{Materials and Methods}

\section{Experimental treatments}

Human acute T-cell leukaemia Jurkat cells (ATCC T1B152) were grown in RPMI 1640 medium supplemented with 10\% foetal calf serum (both from Gibco BRL, Burlington, ON) and $10 \mathrm{mg} / \mathrm{ml}$ gentamycin sulphate (Sigma Chemical Co., St. Louis, MO, USA). Experimental treatments were initiated when cells reach a density of approximately $500000 \mathrm{cells} / \mathrm{ml}$. Cells were synchronized in $\mathrm{G} 1$ by a $16 \mathrm{~h}$ treatment with $2 \mu \mathrm{g} / \mathrm{ml}$ of aphidicolin (from a $10 \mathrm{mg} / \mathrm{ml}$ stock in DMSO; Sigma Chem. Co.), added directly to the freshly changed medium. Apoptosis was induced by the subsequent addition of $100 \mathrm{ng} / \mathrm{ml}$ of mouse monoclonal anti-Fas antibody (Upstate Biotech. Inc., Lake Placid, NY, USA).

\section{Cell viability assays}

Cell viability was assessed by MTT (3,[4,5-dimethylthiazol-2-yl] 2,5diphenyl-tetrazolium bromide) assay, performed as described by Hansen et al. ${ }^{53}$ The formation of blue formazan product was quantified from its absorbance at 570 vs $630 \mathrm{~nm}$ using a Titertech 96-well multiscanner EAR400AT (SLT-Labinstruments, USA). The results were expressed as the percentage of control readings obtained from untreated cells.

\section{Analysis of DNA fragmentation}

Two-dimensional gel electrophoresis of DNA was performed exactly as previously described. ${ }^{28}$

\section{Protein extraction}

Nuclear proteins were extracted as described by Testolin et al..$^{54}$ Total cell extracts were prepared by cell lysis in RIPA buffer $(50 \mathrm{mM}$ Tris- $\mathrm{HCl}, \mathrm{pH}$ 7.4, $150 \mathrm{mM} \mathrm{NaCl}, 2 \mathrm{mM}$ EDTA, $0.1 \%$ SDS, $1 \%$ sodium deoxycholate, $1 \%$ Triton X-100).

\section{Western blotting}

Approximately $60 \mu \mathrm{g}$ of total cellular proteins were separated by $10 \%$ SDS-PAGE and electrotransferred onto a nitrocellulose membrane, as previously described. ${ }^{44}$ The blots were probed with the following primary antibodies: rabbit polyclonal anti-lamin B (dilution of $1: 2000$, kindly provided by Dr. HJ Worman, College of Physicians and Surgeons of University of Columbia, NY, USA), mouse monoclonal anti-NuMA (A-204, dilution of 1:1000, Matritech, Cambridge, MA, USA), rabbit polyclonal anti-SATB1 (dilution 1:5000) ${ }^{21}$ and mouse monoclonal anti-PARP (dilution 1:5000, courtesy of Dr. G Poirier, Faculty of Medicine, Laval University, QC). The antigens were detected using alkaline phosphataseconjugated secondary antibodies: goat anti-mouse-lgG (dilution 1:2000), donkey antirabbit IgG (1:5000), both from Promega, Madison, WI, USA and the complexes were revealed by a colorimetric reaction using BCIP/ NBT substrates (KPL, Gaithersburg, MA, USA).

\section{Immunofluorescence staining}

Cells, settled on poly-L-lysine-coated coverslips, were fixed in $3 \%$ paraformaldehyde (JB EM Services Inc., Pointe Claire, Dorval, $P Q$ ) and permeabilized in $0.2 \%$ Triton X-100 (Pierce/ Chromatographic Specialties Inc., Nepean, ON), as previously described. ${ }^{11}$ Fixed cells were incubated for $1 \mathrm{~h}$ with one of the following primary antibodies, diluted in PBS: antilamin B $(1: 250 \mathrm{v} / \mathrm{v})$, anti-NuMA $(1: 25 \mathrm{v} / \mathrm{v})$ or anti-SATB1 $(1: 500 \mathrm{v} / \mathrm{v})$. Cells were then incubated for $45 \mathrm{~min}$ in the corresponding secondary antibody: FITC-conjugated goat anti-mouse $\lg \mathrm{G}_{(\mathrm{Fc})}(1: 125)$ or CY3- 
a

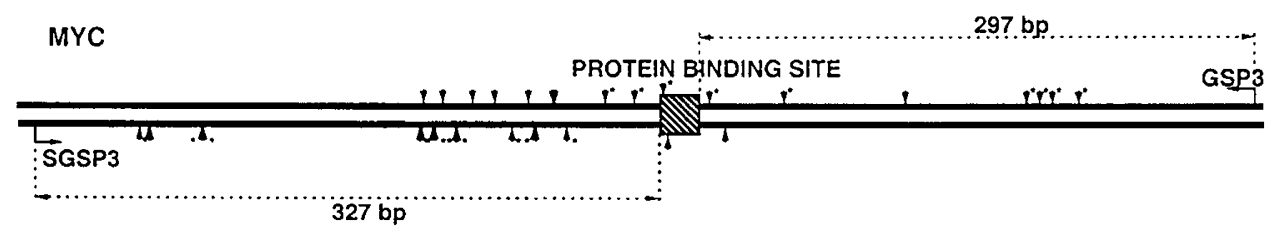

b

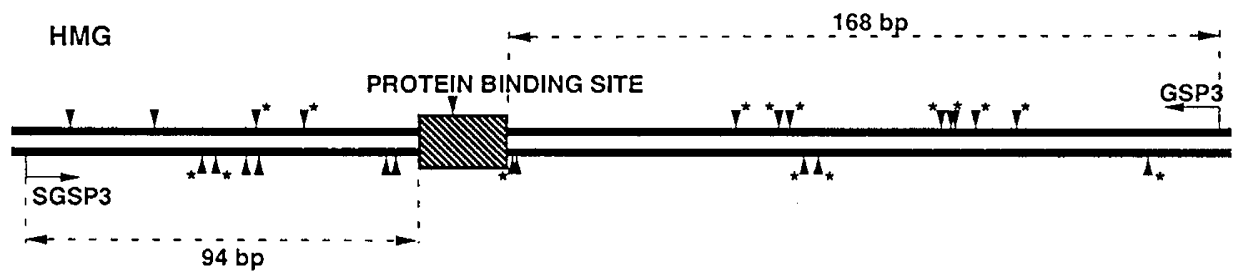

Figure 10 Mapping of ss DNA breaks in the selected regions of c-myc and HMG genes. The exact position of each break was calculated according to the size of the LM-PCR product. Solid lines represent DNA strands; the hatched box indicates the putative protein binding site; arrows illustrate the direction and relative position of the PCR primers used; arrow heads indicate the positions where DNA breaks were detected; asterisks highlight the DNA breaks that were detected more frequently and were represented by a more intense band on the autoradiographs. The distances between the LM-PCR primers (GSP3 and SGSP3) and the protein-binding sites are also indicated

conjugated donkey anti-rabbit IgG $(1: 600$, both Jackson ImmunoResearch/BioCan Scientific, Mississauga, ON). For double staining, antibodies were applied sequentially and $0.15 \%$ gelatin (BioRad, Mississauga, ON) was used as a blocking solution. Finally, nuclei were counterstained with $1 \mu \mathrm{g} / \mathrm{ml}$ of Hoechst 33258 (Sigma) and coverslips were mounted onto slides. The slides were examined using a LeicaWilde-Leitz confocal laser scanning microscope. The images were processed using the system's software and Adobe Photoshop 5.5.

\section{In situ labelling of DNA breaks by TUNEL assay}

DNA breaks were visualized by TUNEL essentially performed as described by Gavrieli et al. ${ }^{55}$ Cells, fixed and labelled with either antiSATB1 or anti-lamin B, were incubated for $1 \mathrm{~h}$ at $37^{\circ} \mathrm{C}$ with $300 \mathrm{U} / \mathrm{ml} \mathrm{TdT}$ in cacodylate buffer (Gibco BRL) containing $10 \mu \mathrm{M}$ biotin-16-dUTP (Boehringer Mannheim, Laval, PQ) and visualized with $10 \mu \mathrm{g} / \mathrm{ml} \mathrm{FITC-} \mathrm{or}$ CY3-conjugated streptavidin (Jackson ImmunoResearch). The cells were examined on a Leica-Wilde-Leitz confocal laser scanning microscope and images were processed using the system's software and Adobe Photoshop 5.5.

\section{EMSA and SW}

Complementary strands of oligonucleotides (Table 2) were synthesized by the phosphoroimidate method on an Applied Biosystem 8905 Synthesizer. They were annealed and $3^{\prime}$-end labelled using the Klenow fragment of DNA polymerase I, [ $\left[{ }^{32} \mathrm{P}\right] \mathrm{dATP}$ and $\left[{ }^{32} \mathrm{P}\right] \mathrm{dGTP}$ (specific activity $800 \mathrm{Ci} /$ mmol, NEN, Mississauga, ON). The probes were purified using Nick columns (Amersham Pharmacia, Baie d'Urfe, QC). The EMSA was carried out as previously described. ${ }^{56}$ The SW hybridization technique was adapted from a previously described method. ${ }^{56}$ Briefly, nuclear proteins, approximately $60 \mu \mathrm{g} /$ lane, were separated by $10 \%$ SDS-PAGE, renatured

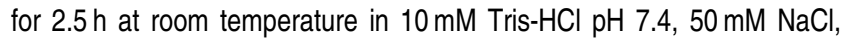
$2 \mathrm{mM}$ EDTA, $0.1 \mathrm{mM}$ DTT and $4 \mathrm{M}$ urea, and electrotransferred onto nitrocellulose membranes. The filters were blocked for $1 \mathrm{~h}$ at room temperature with $5 \%(\mathrm{w} / \mathrm{v})$ milk powder in a blocking buffer and incubated for an additional $3 \mathrm{~h}$ at room temperature with $0.2-0.5 \mu \mathrm{g}$ of $3^{\prime}$-end- labelled ds oligonucleotides $\left(10^{5} \mathrm{cpm} / \mathrm{ng}\right)$, and $200 \mu \mathrm{g}$ of poly $(\mathrm{dl}-\mathrm{dC})$ (Pharmacia) in $20 \mathrm{ml}$ of the blocking buffer. The filters were washed twice with the blocking buffer without $\mathrm{NaCl}$, followed by the final rinse in $10 \mathrm{mM}$ Tris, $1 \mathrm{mM} \mathrm{MgCl}$, $\mathrm{pH}$ 8.0. They were air dried and autoradiographed on Kodak Biomax MS films.

\section{Isolation of genomic DNA}

Genomic DNA was isolated according to the procedure described by Ausubel et al. ${ }^{57}$ RNA contamination was eliminated by treatment of the DNA with $4 \mu \mathrm{g}$ of RNase A for 30 min at room temperature. The DNA was further extracted with phenol/chloroform and precipitated with ethanol. The genomic DNA was then digested with selected restriction enzymes, chosen to avoid cutting of the DNA within the stretches amplified by the PCR and LM-PCR primers used (Table 3). The digested DNA was again purified by phenol/chloroform extraction and was precipitated with ethanol. This step was introduced in order to assure that both control and apoptotic DNA were equally fragmented and thus equally accessible to the primers and the DNA polymerase during the PCR steps.

\section{PCR and ligation-mediated PCR}

The sequences of all PCR primers, their location and the expected fragment sizes are listed in Table 3.

For the conventional PCR, a $20 \mathrm{ng} /$ sample of the digested DNA template was used. The primers used to amplify intact DNA fragments spanning the SATB1-like binding site were designated CS for the sense strand and $\mathrm{CP}$ for the antisense strand and, to amplify DNA fragments outside the protein-binding site, OS and OP, respectively (Figure 6a). The PCR was performed as follows: one denaturation cycle at $94^{\circ} \mathrm{C}$ for $5 \mathrm{~min}$, followed by 35 cycles of $94^{\circ} \mathrm{C}$ for $1 \mathrm{~min}, 60^{\circ} \mathrm{C}$ for $1 \mathrm{~min}$ and $72^{\circ} \mathrm{C}$ for $50 \mathrm{~s}$. In the last cycle, the products were kept at $72^{\circ} \mathrm{C}$ for an additional $5 \mathrm{~min}$. One-fifth of each reaction was separated on a $1 \%$ agarose gel, stained with ethidium bromide and photographed.

The LM-PCR was performed using a modified protocol described by Ausubel et al. ${ }^{57}$ Sense, gene-specific primers (SGSPs) were used to detect ss breaks on the antisense strand of the genomic DNA and gene- 
specific primers (GSPs) to identify ss breaks on the sense strand of the genomic DNA. The assay was performed using $2 \mu \mathrm{g}$ per sample of restriction digested genomic DNA. The DNA was denatured and first annealed with the GSP1 primers. The first-strand synthesis was accomplished with Vent DNA polymerase (NE Biolabs, Beverly, MA, USA). The ds blunt end DNA was then ligated with the staggered linker DNA. The first round PCR reaction was performed by extending the newly synthesized first DNA strand at $72^{\circ} \mathrm{C}$ for $3 \mathrm{~min}$ in the presence of $0.5 \mu \mathrm{l}$ of the advantage Taq DNA polymerase (Clontech, Palo Alto, CA, USA), to displace the short-strand linker DNA so that this DNA strand becomes the template for the remaining PCR cycles. Following addition of the GSP2 and the linker primers, a further 18 PCR cycles were completed and the final cycle was done in the presence of $\left[{ }^{32} \mathrm{P}\right]$-labelled GSP3 primers. The $\left.{ }^{32} \mathrm{P}\right]$ - labelled PCR products were visualized on a polyacrylamide DNA sequencing gel with a known DNA sequencing reaction running along the side to determine the size of each PCR product. In a parallel experiment, the restriction enzyme-digested DNA was phosphorylated with 10 units of T4 polynucleotide kinase (NE Biolabs, Beverly, MA, USA) prior to the LMPCR reaction. The steps required for the completion of LM-PCR are outlined in Figure 7.

\section{Acknowledgments}

We thank Harvey Miller for the Genbank searches, Julie Leblanc for the 2D-PFGE, and Tom Devecseri for the figure preparation.

\section{References}

1. Walker PR and Sikorska M (1997) New aspects of the mechanism of DNA fragmentation in apoptosis. Biochem. Cell. Biol. 75: 287-299

2. Sikorska M and Walker PR (1998) Endonuclease activities and apoptosis. In: Lockshin RA, Zakeri Z, Tilley JL, eds. When Cells Die. New York: Wiley-Liss, Inc, pp. 211-242

3. Probst $\mathrm{H}$ and Herzog R (1985) DNA regions associated with the nuclear matrix of Ehrlich ascites cells expose single-stranded sites after deproteinization. Eur. J. Biochem. 146: 167-171

4. Peitsch MC, Muller C and Tschopp J (1993) DNA fragmentation during apoptosis is caused by frequent single-strand cuts. Nucleic. Acids. Res. 21: 4206-4209

5. Luderus ME, den Blaauwen JL, de Smit OJ, Compton DA and van Driel R (1994) Binding of matrix attachment regions to lamin polymers involves single- stranded regions and the minor groove. Mol. Cell Biol 14: $6297-6305$

6. Lagarkova MA, larovaia OV and Razin SV (1995) Large-scale fragmentation of mammalian DNA in the course of apoptosis proceeds via excision of chromosomal DNA loops and their oligomers. J. Biol. Chem. 270: 2023920241

7. Walker PR, LeBlanc J and Sikorska M (1997) Evidence that DNA fragmentation in apoptosis is initiated and propagated by single-strand breaks. Cell Death Differ. 4: 506-515

8. Kaufmann SH, Desnoyers S, Ottaviano Y, Davidson NE and Poirier GG (1993) Specific proteolytic cleavage of poly(ADP-ribose) polymerase: an early marker of chemotherapy-induced apoptosis. Cancer Res 53: 3976-3985

9. Neamati N, Fernandez A, Wright S, Kiefer J and McConkey DJ (1995) Degradation of lamin B1 precedes oligonucleosomal DNA fragmentation in apoptotic thymocytes and isolated thymocyte nuclei. J. Immunol 154: 37883795

10. Tewari M, Quan LT, O'Rourke K, Desnoyers S, Zeng Z, Beidler DR, Poirier GG, Salvesen GS and Dixit VM (1995) Yama/CPP32 beta, a mammalian homolog of CED-3, is a CrmA-inhibitable protease that cleaves the death substrate poly(ADP-ribose) polymerase. Cell 81: 801-809

11. Weaver VM, Carson CE, Walker PR, Chaly N, Lach B, Raymond Y, Brown DL and Sikorska M (1996) Degradation of nuclear matrix and DNA cleavage in apoptotic thymocytes. J. Cell Sci. 109: 45-56
12. Buendia B, Santa-Maria A and Courvalin JC (1999) Caspase-dependent proteolysis of integral and peripheral proteins of nuclear membranes and nuclear pore complex proteins during apoptosis. J. Cell Sci. 112: 1743-1753

13. Galande S and Kohwi-Shigematsu T (1999) Poly(ADP-ribose) polymerase and $\mathrm{Ku}$ autoantigen form a complex and synergistically bind to matrix attachment sequences. J. Biol. Chem. 274: 20521-20528

14. Craig JM, Boyle S, Perry P and Bickmore WA (1997) Scaffold attachments within the human genome. J. Cell Sci. 110: 2673-2682

15. Bode J, Benham C, Knopp A and Mielke C (2000) Transcriptional augmentation: modulation of gene expression by scaffold/matrixattached regions (S/MAR elements). Crit. Rev. Eukaryot. Gene Expr. 10: 73-90

16. Chernov IP, Akopov SB, Nikolaev LG and Sverdlov ED (2000) Identification and mapping of nuclear matrix-attachment regions in a one megabase locus of human chromosome 19q13.12: long-range correlation of S/MARs and gene positions. J. Cell Biochem. 84: 590-600

17. Liebich I, Bode J, Frisch M and Wingender E (2002) S/MARt DB: a database on scaffold/matrix attached regions. Nucleic Acids Res. 30: 372-374

18. Kohwi-Shigematsu T and Kohwi Y (1990) Torsional stress stabilizes extended base unpairing in suppressor sites flanking immunoglobulin heavy chain enhancer. Biochemistry 29: 9551-9560

19. Benham C, Kohwi-Shigematsu T and Bode J (1997) Stress-induced duplex DNA destabilization in scaffold/matrix attachment regions. J. Mol. Biol. 274: 181-196

20. Bode J, Kohwi Y, Dickinson L, Joh T, Klehr D, Mielke C and Kohwi-Shigematsu T (1992) Biological significance of unwinding capability of nuclear matrixassociating DNAs. Science 255: 195-197

21. Dickinson LA, Joh T, Kohwi Y and Kohwi-Shigematsu T (1992) A tissue-specific MAR/SAR DNA-binding protein with unusual binding site recognition. Cell 70 : 631-645

22. Kohwi-Shigematsu T, deBelle I, Dickinson LA, Galande S and Kohwi Y (1998) Identification of base-unpairing region-binding proteins and characterization of their in vivo binding sequences. Methods Cell Biol. 53: 323-354

23. Herrscher RF, Kaplan MH, Lelsz DL, Das C, Scheuermann R and Tucker PW (1995) The immunoglobulin heavy-chain matrix-associating regions are bound by Bright: a B cell-specific trans-activator that describes a new DNA-binding protein family. Genes Dev. 9: 3067-3082

24. Liu WM, Guerra-Vladusic FK, Kurakata S, Lupu R and Kohwi-Shigematsu T (1999) HMG-I(Y) recognizes base-unpairing regions of matrix attachment sequences and its increased expression is directly linked to metastatic breast cancer phenotype. Cancer Res. 59: 5695-5703

25. Gotzmann J, Meissner M and Gerner $C$ (2000) The fate of the nuclear matrixassociated-region-binding protein SATB1 during apoptosis. Cell Death Differ 7: 425-438

26. Kipp M, Schwab BL, Przybylski M, Nicotera $P$ and Fackelmayer FO (2000) Apoptotic cleavage of scaffold attachment factor A (SAF-A) by caspase-3 occurs at a noncanonical cleavage site. J. Biol. Chem. 275: 50315036

27. deBelle I, Cai S and Kohwi-Shigematsu T (1998) The genomic sequences bound to special AT-rich sequence-binding protein 1 (SATB1) in vivo in Jurkat T cells are tightly associated with the nuclear matrix at the bases of the chromatin loops. J. Cell Biol 141: 335-348

28. Walker PR, LeBlanc J, Smith B, Pandey S and Sikorska M (1999) Detection of DNA fragmentation and endonucleases in apoptosis. Methods 17: 329-338

29. Galande S, Dickinson LA, Mian IS, Sikorska M and Kohwi-Shigematsu T (2001) SATB1 cleavage by caspase 6 disrupts PDZ domain-mediated dimerization, causing detachment from chromatin early in T-cell apoptosis. Mol. Cell Biol. 21: 5591-5604

30. Ramakrishnan M, Liu WM, DiCroce PA, Posner A, Zheng J, Kohwi-Shigematsu T and Krontiris TG (2000) Modulated binding of SATB1, a matrix attachment region protein, to the AT-rich sequence flanking the major breakpoint region of BCL2. Mol. Cell Biol. 20: 868-877

31. Kidd VJ, Lahti JM and Teitz T (2000) Proteolytic regulation of apoptosis. Semin. Cell Dev. Biol. 11: 191-201

32. Casiano CA, Martin SJ, Green DR and Tan EM (1996) Selective cleavage of nuclear autoantigens during CD95 (Fas/APO-1)- mediated T cell apoptosis. J. Exp. Med. 184: 765-770 
33. Nakagomi K, Kohwi Y, Dickinson LA and Kohwi-Shigematsu T (1994) A nove DNA-binding motif in the nuclear matrix attachment DNA-binding protein SATB1. Mol. Cell Biol. 14: 1852-1860

34. Gohring F, Schwab BL, Nicotera P, Leist $M$ and Fackelmayer FO (1997) The novel SAR-binding domain of scaffold attachment factor A (SAF-A) is a target in apoptotic nuclear breakdown. EMBO J. 16 7361-7371

35. Oberhammer FA, Hochegger K, Froschl G, Tiefenbacher R and Pavelka M (1994) Chromatin condensation during apoptosis is accompanied by degradation of lamin $\mathrm{A}+\mathrm{B}$, without enhanced activation of cdc2 kinase. J. Cell Biol. 126: 827-837

36. Gromova II, Nielsen OF and Razin SV (1995) Long-range fragmentation of the eukaryotic genome by exogenous and endogenous nucleases proceeds in a specific fashion via preferential DNA cleavage at matrix attachment sites. J. Biol. Chem. 270: 18685-18690

37. Schoenlein PV, Barrett JT and Welter D (1999) The degradation profile of extrachromosomal circular DNA during cisplatin-induced apoptosis is consistent with preferential cleavage at matrix attachment regions. Chromosoma 108: 121-131

38. Filipski J, LeBlanc J, Youdale T, Sikorska M and Walker PR (1990) Periodicity of DNA folding in higher order chromatin structures. EMBO J. 9 : 1319-1327

39. Khodarev NN, Bennett T, Shearing N, Sokolova I, Koudelik J, Walter S, Villalobos M and Vaughan AT (2000) LINE L1 retrotransposable element is targeted during the initial stages of apoptotic DNA fragmentation. J. Cell Biochem. 79: 486-495

40. Cairns MJ and Murray V (1998) Detection of protein-DNA interactions at betaglobin gene cluster in intact human cells utilizing hedamycin as DNA-damaging agent. DNA Cell Biol. 17: 325-333

41. Schmid C, Heng HH, Rubin C, Ye CJ and Krawetz SA (2001) Sperm nuclear matrix association of the PRM1 $\rightarrow$ PRM2 $\rightarrow$ TNP2 domain is independent of Alu methylation. Mol. Hum. Reprod. 7: 903-911

42. Chou RH, Churchill JR, Flubacher MM, Mapstone DE and Jones J (1990) Identification of a nuclear matrix-associated region of the c-myc protooncogene and its recognition by a nuclear protein in the human leukemia $\mathrm{HL}-60$ cell line. Cancer Res. 50: 3199-3206

43. Baron WF, Pan CQ, Spencer SA, Ryan AM, Lazarus RA and Baker KP (1998) Cloning and characterization of an actin-resistant DNase l-like endonuclease secreted by macrophages. Gene 215: 291-301

44. Liu QY, Pandey S, Singh RK, Lin W, Ribecco M, Borowy-Borowski H, Smith B, LeBlanc J, Walker PR and Sikorska M (1998) DNaseY: a rat DNasel-like gene coding for a constitutively expressed chromatin-bound endonuclease. Biochemistry 37: 10134-10143
45. Shiokawa D and Tanuma S (1998) Molecular cloning and expression of a cDNA encoding an apoptotic endonuclease DNase gamma. Biochem J. 332: 713720

46. Yakovlev AG, Wang G, Stoica BA, Simbulan-Rosenthal CM, Yoshihara $K$ and Smulson ME (1999) Role of DNAS1L3 in $\mathrm{Ca}^{2+}$ - and $\mathrm{Mg}^{2+}$-dependent cleavage of DNA into oligonucleosomal and high molecular mass fragments. Nucleic Acids Res. 27: 1999-2005

47. Enari M, Sakahira H, Yokoyama H, Okawa K, Iwamatsu A and Nagata S (1998) A caspase-activated DNase that degrades DNA during apoptosis, and its inhibitor ICAD. Nature 39: 43-50

48. Boulares AH, Zoltoski AJ, Yakovlev A, Xu M and Smulson ME (2001) Roles of DNA fragmentation factor and poly(ADP-ribose) polymerase in an amplification phase of tumor necrosis factor-induced apoptosis. J. Biol. Chem. 276: 3818538192

49. Sakahira H, Enari M, Ohsawa $Y$ and Uchiyama $Y$ (1990) Apoptotic nuclear morphological; change without DNA fragmentation. Curr. Biol. 9: 543-546

50. Samejima K, Tone S and Earnshaw W (2001) CAD/DFF40 nuclease is dispensible for high molecular weight DNA cleavage and stage I chromatin condensation in apoptosis. J. Biol. Chem. 276: 45427-45432

51. Tomei LD, Shapiro JP and Cope FO (1993) Apoptosis in C3H/10T1/2 mouse embryonic cells: evidence for internucleosomal DNA modification in the absence of double-strand cleavage. Proc. Natl. Acad. Sci. USA 90: 853-857

52. Chen J, Jin K, Chen M, Pei W, Kawaguchi K, Greenberg DA and Simon RP (1997) Early detection of DNA strand breaks in the brain after transient focal ischemia: implications for the role of DNA damage in apoptosis and neuronal cell death. J. Neurochem. 69: 232-245

53. Hansen MB, Nielsen SE and Berg K (1989) Re-examination and further development of a precise and rapid dye method for measuring cell growth/cell kill. J. Immunol. Methods 119: 203-210

54. Testolin L, Carson C, Wang Y, Walker PR, Armato U and Sikorska M (1997) Jun and JNK kinase are activated in thymocytes in response to VM26 and radiation but not glucocorticoids. Exp. Cell Res. 230: 220-232

55. Gavrieli Y, Sherman $Y$ and Ben Sasson SA (1992) Identification of programmed cell death in situ via specific labeling of nuclear DNA fragmentation. J. Cell Biol. 119: 493-501

56. Kwast-Welfeld J, deBelle I, Walker PR, Whitfield JF and Sikorska M (1993) Identification of a new cAMP response element-binding factor by Southwestern blotting. J. Biol. Chem. 268: 19581-19585

57. Ausubel FM, Brent R, Kingston RE, Moore DD, Smith JA, Seidman JG and Struhl K (1987). Current Protocols in Molecular Biology. New York: John Wiley and Sons Inc 